\title{
DYNAMICS OF CARRIER DECAY IN PROTON AND $\gamma$-RAY IRRADIATED HIGH-RESISTIVITY Si *
}

\author{
E. Gaubas and M. Bauža \\ Institute of Materials Science and Applied Research, Vilnius University, Sauletekio 10, LT-10223 Vilnius, Lithuania \\ E-mail: eugenijus.gaubas@ff.vu.lt
}

Received 7 July 2005

\begin{abstract}
Excess carrier lifetime variations in proton and $\gamma$-ray irradiated $\mathrm{MCz}$ Si have been examined. The linear decrease of recombination lifetime with dose in $\gamma$-ray irradiated material shows a dose-independent defect introduction rate, while protons of high fluence induce changes of the type of the dominant radiation defects. The simultaneous recombination and trapping components in the carrier decay transients were revealed by microwave absorption technique. Two peaks were separated in recombination and trapping lifetime variations with temperature. Trap activation factors were extracted. The dominant defects acting as recombination and trapping centres are discussed.
\end{abstract}

Keywords: recombination and trapping, radiation defects, microwave absorption transients

PACS: $61.72 . J i, 61.82 . \mathrm{Fk}, 72.40 .+\mathrm{w}$

\section{Samples and irradiations}

Standard technologies of the particle detectors are based on high-resistivity (HR) Si [1]. In recent years, strong interest has appeared in the heat treatment technologies to suppress the harmful radiation defects [24]. However, the intrinsic, thermally induced, and radiation defects set a wide spectrum of recombination and trapping centres. Interplay of these centres significantly modifies the recombination and electrical characteristics of the material and detectors. The noninvasive techniques to control these defects and their transforms are desirable. These techniques allow one to extract defect parameters in contactless way, to perform in situ measurements in rapid mode. Application of the dynamic methods is very useful, when direct information about recombination processes is derived from various characteristics of carrier decay, employing carrier lifetime variations dependent on temperature, carrier density, and excitation spectrum. Development of transient contactless techniques, applicable during thermal treatments and irradiations, is necessary in modern material characterization technology.

In this work, the carrier lifetime variations in starting and irradiated material wafers and diode structures were investigated to reveal the electrically active de-

\footnotetext{
* The report presented at the 36th Lithuanian National Physics Conference, 16-18 June 2005, Vilnius, Lithuania.
}

fects in the silicon detector material. Measurements of recombination parameters were performed by a noninvasive technique of microwave absorption transients caused by free carrier density variations.

Three batches of samples were investigated. The first one was composed of homogeneous $n$ - and $p$-type magnetic Czochralski (MCz) Si wafers with dimensions of $20 \times 20 \mathrm{~mm}^{2}$ and of $300 \mu \mathrm{m}$ thickness. The $10 \mathrm{MeV}$ and $50 \mathrm{MeV}$ proton irradiations with different fluences (of $5 \cdot 10^{12}$ and $10^{13} \mathrm{p} / \mathrm{cm}^{2}$ at $10 \mathrm{MeV}$ as well as of $9 \cdot 10^{12}$ and $2 \cdot 10^{13} \mathrm{p} / \mathrm{cm}^{2}$ at $50 \mathrm{MeV}$ ) were utilized. The second batch of samples consisted of pad-detectors fabricated on oxygen doped flat zone (DOFZ) $n$-type $\mathrm{Si}$, with introduced oxygen by a high-temperature 24 hour diffusion step, and nonprocessed FZ Si diodes for comparison. These detectors were irradiated by $24 \mathrm{GeV}$ protons with $4 \cdot 10^{14}$ and $10^{15} \mathrm{p} / \mathrm{cm}^{2}$ fluences. The third batch of the MCz sample pairs were irradiated with ${ }^{60} \mathrm{Co} \gamma$-rays in the range of doses of 50, 80, 160, 270, and $320 \mathrm{Mrad}$, respectively. A complementary sample of pad-detector, fabricated on $n$-type standard FZ Si and irradiated with $400 \mathrm{Mrad}{ }^{60} \mathrm{Co} \gamma$-rays, was examined.

Excess carrier recombination transients were examined by combining analyses of the excess carrier decays dependent on the excitation intensity, bias illumination, and temperature, measured using a microwave absorption technique (MWA) [5]. Excess carriers were 
generated in bulk of the samples by a $1064 \mathrm{~nm}$ wavelength light of the YAG: $\mathrm{Nd}^{3+}$ laser with $10 \mathrm{~ns}$ pulse duration and probed by microwaves (at $10 \mathrm{GHz}$ ). Continuous wave (cw) bias illumination (BI) was employed to suppress trapping by varying the filling state of the capture levels. The samples were placed on cold/hot finger to measure the lifetime variations dependent on temperature from which the trap activation factors were deduced.

\section{Carrier decay dynamics dependent on fluence and temperature}

At room temperature, MWA transients in the starting material wafers of $p$ - and $n$-type $\mathrm{MCz} \mathrm{Si}$, measured at relatively low excitation without bias $\mathrm{cw}$ illumination, exhibited a two-componential decay. Variations of the excess carrier decay transients in $\mathrm{MCz}$ Si material, determined by excitation conditions, are illustrated in the inset of Fig. 1(a). Asymptotic constituent exhibited very long (up to tens of ms) lifetimes, manifesting the competition of carrier recombination and trapping processes. The recombination and trapping lifetimes decrease with excitation intensity due to the filling of defect levels. The trapping constituent almost disappears at the highest excitation intensities in the initial material. Bias illumination partially or fully suppresses the trapping long-tail constituent in the as-grown material. Carrier lifetime dramatically decreases in the samples post-irradiated with protons even at the lowest fluences applied. Then, the decay is one-componential in proton-irradiated material, while two-componential decay is inherent for $\gamma$-irradiated material.

Significant carrier lifetime variations were obtained by varying the irradiation fluence, when decays were examined at room temperature (RT). Reciprocal lifetime $\left(\tau^{-1}\right)$ as a function of proton irradiation fluence and $\gamma$-ray dose is shown in Figs. 1(a) and 1(b), respectively. Such a plot allows one to extract the defect introduction rates and to monitor the radiation defect concentrations since $\tau^{-1}$ is proportional to the radiation defect density. The different slopes can be deduced by a linear approximation of segments in various proton fluence ranges of this characteristic in Fig. 1(a). Here, the $\tau^{-1}$ dependence on fluence is generalized for both $n$ - and $p$-type wafers and detector samples. Variation of the slope in different fluence ranges implies that not only the concentration of defects $R$, but also their type can vary with fluence. In the range of low fluences the slope appeared to be dependent on the distance among

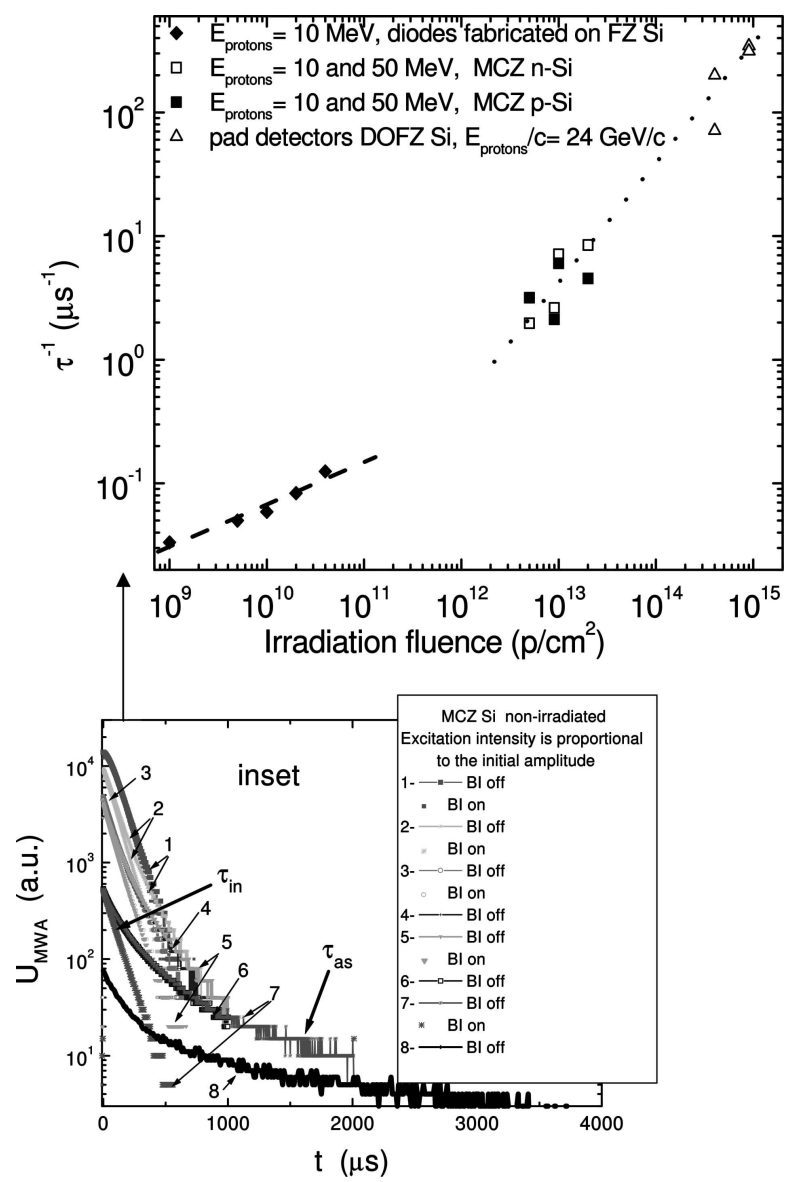

(a)

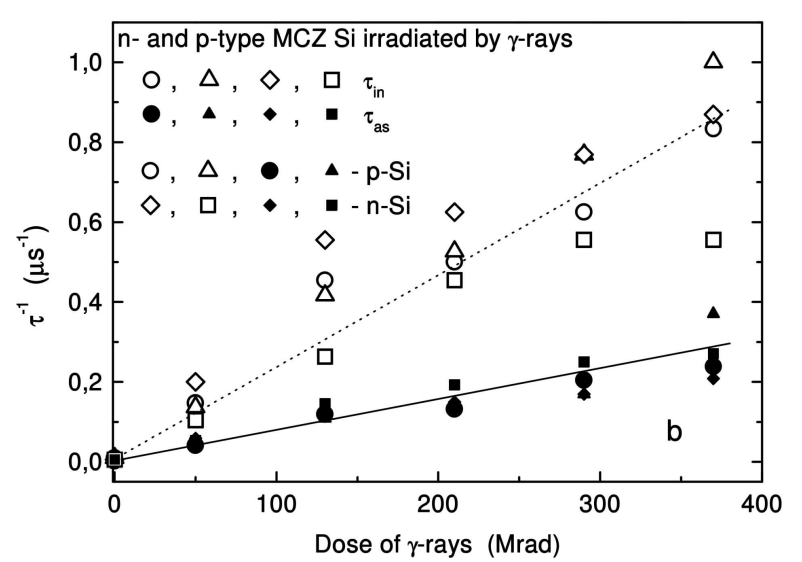

(b)

Fig. 1. Reciprocal lifetime versus (a) proton irradiation fluence and (b) $\gamma$-ray irradiation dose, measured in different samples of $p$ - and $n$-type Si at RT. Inset of (a): variations of MWA transients in $\mathrm{MCz}$ Si material conditioned by excitation regimes, when pulsed excitation intensity is proportional to the amplitude of the photoresponse.

recombination centres, when $\tau_{R}^{-1} \propto R^{1 / 3}$. Defect conglomerates or clusters act as extended centres characterized by a steeper slope segment at higher fluences. This is partially corroborated by the different activation energies of capture centres $(0.23 \mathrm{eV}$ and $0.3 \mathrm{eV})$ 
estimated for $n$-type wafers and pad detectors irradiated by protons in the ranges of moderate and high fluences, respectively.

Inverse lifetime in the $\gamma$-ray irradiated material (shown in Fig. 1(b)) exhibits nearly linear increase with irradiation dose for both $n$ - and $p$-type materials, but with different slopes for the recombination and the trapping centres, inherent for $n$ - and $p$-type samples. This manifests different introduction rates for recombination and trapping defects. However, slopes with $\alpha<1$ in the dependence $\tau_{R}^{-1} \propto N_{\gamma}^{\alpha}$ imply the dominance of $\gamma$-ray induced point defects of concentration $N_{\gamma}$ for both the recombination and the trapping centres.

In addition, the carrier lifetime in the samples irradiated with a fixed fluence appeared to be dependent on temperature, the latter being varied in the interval from 90 to $450 \mathrm{~K}$. These dependences are illustrated for proton and $\gamma$-ray irradiated $\mathrm{MCz}$ Si in Figs. 2(a) and 2(b), respectively. Two peaks of carrier lifetime values were obtained in the ranges of low and elevated (above RT) temperature (Fig. 2(a)) in the proton irradiated material, while only a low temperature peak and a lifetime increase wing were observed in the $\gamma$-ray irradiated $\mathrm{Si}$. The low-temperature peak is mainly conditioned by a trapping which appears as a long-tail decay constituent. Evolution of MWA transients in $\gamma$-ray post-irradiated material is illustrated in the inset of Fig. 2(b), where rapid changes of the asymptotic decay component relatively to the initial one can be observed. However, the asymptotic constituent, ascribed to trapping, is nearly independent of $\mathrm{BI}$ (in the range of cw BI intensities applied). Therefore, the shape of this lifetime peak seems to be slightly modified by the competing recombination centres characterized by lifetimes ascribed to the initial decay constituent. The latter is determined by the recombination centres that are electrically active in the definite temperature range. This peak of the trapping lifetime is inherent for all the irradiated samples. Variation of the absolute lifetime values in samples irradiated by different proton fluences is shown in Fig. 2(a). It is worth noting that in the starting material, the lifetime versus temperature variations were not resolvable due to small concentration of the intrinsic defects.

Variations of the short decay component, which prevails in the proton irradiated samples at elevated temperatures, form a high-temperature peak, shown for one sample of $n$-type $\mathrm{MCz} \mathrm{Si}$. The trap activation factors were deduced by using the lifetime as a function of $1 / k T$ plots. In the $n$-type wafers, the dominant slopes exhibited the effective trap activation energy values of $0.56 \mathrm{eV}, 0.23 \mathrm{eV}$, and $0.1 \mathrm{eV}$. In the $n$-type DOFZ pad

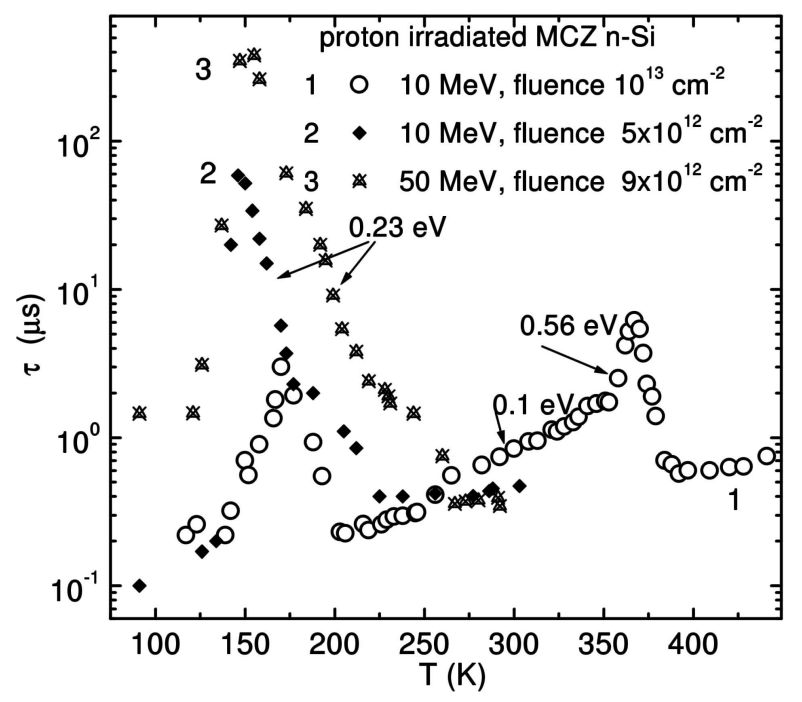

(a)

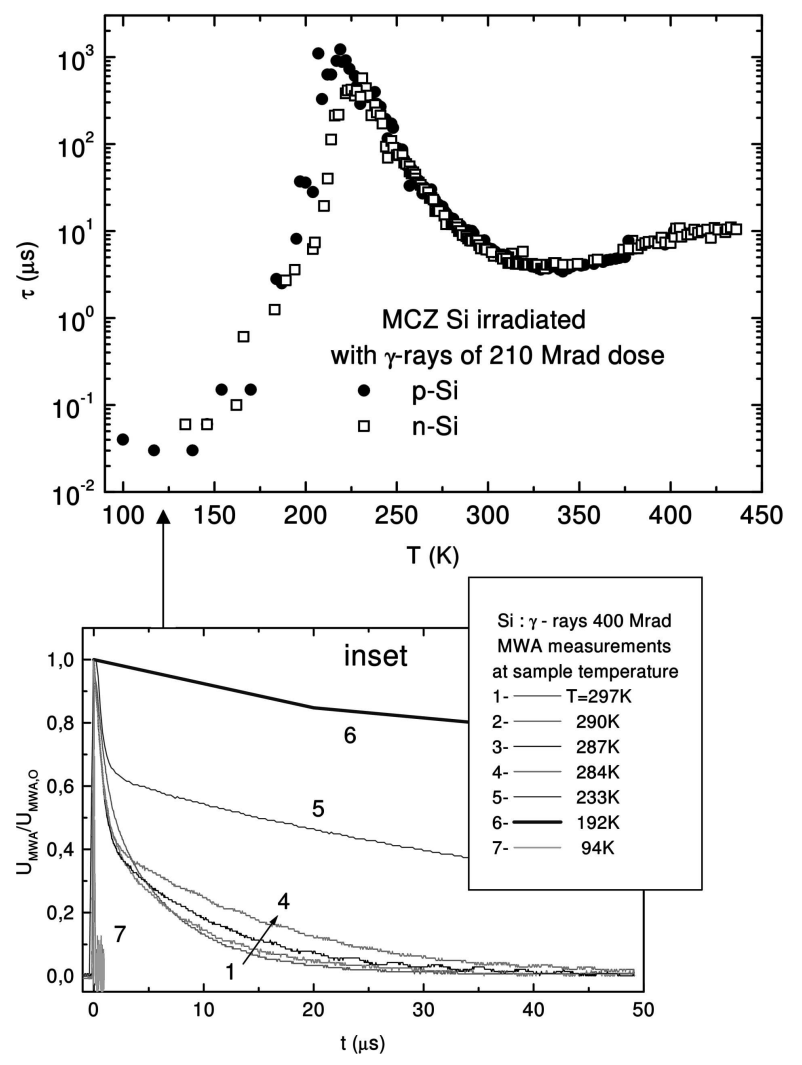

(b)

Fig. 2. Carrier lifetime temperature variations due to trapping and recombination in wafers irradiated with (a) protons of different fluences and (b) $\gamma$-rays with 210 Mrad dose. Inset of (b): evolution of MWA normalized transients in $\gamma$-ray post-irradiated material.

detectors irradiated with proton fluences of $4 \cdot 10^{14}$ and $10^{15} \mathrm{p} / \mathrm{cm}^{2}$, the dominant trapping level is characterized by activation energy of $0.3 \mathrm{eV}$. In $p$-type $\mathrm{MCz} \mathrm{Si}$ material, effective trap activation energy values were found to be of $0.4 \mathrm{eV}, 0.19 \mathrm{eV}$, and $0.1 \mathrm{eV}$. 
In the $\gamma$-ray irradiated $\mathrm{MCz} \mathrm{Si}$ material, effective trap activation energy values of $(0.14-0.17) \mathrm{eV}$ were extracted within carrier lifetime enhancement wing at elevated temperatures. The dominant trapping level, characterized by activation energy of $(0.36-0.38) \mathrm{eV}$, was deduced from the lifetime variation slope within range of the lifetime peak in the low temperature $(T<$ $250 \mathrm{~K}$ ) range.

Considering the samples with different concentrations of activated oxygen defects, the oxygen attributed centres probably can be associated with shallow levels characterized by the activation energy of 0.07 and $0.15 \mathrm{eV}$ [3] and with trapping centres having the activation energy in the range of $(0.1-0.15) \mathrm{eV}$ (Figs. 2(a) and 2(b)).

Summarizing, the observed lifetime dependences on temperature (Fig. 2) can be explained by simultaneous interplay of recombination and trapping centres, when the trapping effect is resolvable for trapping coefficients $\gg 1$. Trapping coefficient is mainly determined by the concentration of trapping centres $M$. Therefore, in the starting material wafers with small $M$, the trapping peak in the lifetime temperature dependencies was non-resolvable for the excitations applied. The extracted trap activation energy effective values of $0.56 \mathrm{eV}, 0.23 \mathrm{eV}$, and $0.1 \mathrm{eV}$ can be attributed to divacancy and thermal donors $[3,6]$ after proton irradiations in the range of moderate fluences. The activation energy values, extracted by employing the MWA technique, are close to those measured by capacitance deep level transient spectroscopy (DLTS). In the $n$-Si pad detectors irradiated with high proton fluences of $4 \cdot 10^{14}$ and $10^{15} \mathrm{~cm}^{-2}$, the dominant trapping level is characterized by the activation energy of $0.3 \mathrm{eV}$, which may be associated with interstitials of Si and vacancy complexes [6]. In proton irradiated $p$-type material, the extracted trap activation energy values of $0.4 \mathrm{eV}$, $0.19 \mathrm{eV}$, and $0.1 \mathrm{eV}$ can be attributed to di-vacancy, vacancy-oxygen (VO) complex, and thermal donors, respectively. In $\gamma$-ray irradiated material, the trapping level dominates and it is characterized by activation energy of $(0.36-0.38) \mathrm{eV}$. These centres may be associated with vacancies and VO complexes [6].

\section{Conclusions}

It has been demonstrated that analyses of the various carrier decay characteristics by non-invasive MWA technique can be a powerful tool for evaluation of the parameters of radiation induced defects. The inverse lifetime of the fast recombination, estimated from
MWA decays, exhibited the nonlinear variation with proton irradiation fluence. This can be explained by a change of the defect formation rate and defect types ascribed to the ranges of moderate and the highest irradiation fluences. It was determined that the inverse lifetime-dose dependences in $\gamma$-ray irradiated material can be approximated linearly. Activation factors of the fast recombination centres and of the slow trapping ones, extracted from the carrier lifetime variations with temperature in irradiated samples, correspond well to conventional vacancy attributed radiation defects in $\mathrm{Si}$. Specifically, for $n$-Si, the centres characterized by values of 0.56 and $0.23 \mathrm{eV}$ can be attributed to di-vacancy in proton irradiated samples within the range of moderate fluences, and the centres with activation energy of $0.3 \mathrm{eV}$ may be associated with interstitials of $\mathrm{Si}_{\mathrm{i}}$ and vacancy complexes. For $p$-Si, trap activation energy values of 0.4 and $0.19 \mathrm{eV}$ can be attributed to divacancy and VO complex, respectively. In $\gamma$-ray irradiated material, the dominant defect with activation energy of $(0.36-0.38) \mathrm{eV}$ may be associated with vacancies and VO complexes.

\section{Acknowledgements}

This work was performed in the frame of the CERN RD39 and RD50 Projects and was partly supported by Lithuanian State Science and Studies Foundation.

\section{References}

[1] www.cern.ch/rd50.

[2] A. Sassella, A. Borghesi, and T. Abe, Quantitative evaluation of precipitated oxygen in silicon by infrared spectroscopy, J. Electrochem. Soc. 145, 1715 (1998).

[3] E. Simoen, C. Claeys, R. Loo, O. De Gryse, P. Clauws, R. Job, A.G. Ulyashin, and W. Fahrner, Characterisation of oxygen and oxygen-related defects in highlyand lowly-doped silicon, Mater. Sci. Eng. B 102, 207 (2003).

[4] E. Verbitskaya, M. Abreu, P. Anbinderis, T. Anbinderis, N. D’Ambrosio, W. de Boer, E. Borchi, K. Borer, M. Bruzzi, S Buontempo et al., The effect of charge collection recovery in silicon $p-n$ junction detectors irradiated by different particles, Nucl. Instrum. Methods A 514, 47 (2003).

[5] E. Gaubas, Transient absorption techniques for investigation of recombination properties in semiconductor materials, Lithuanian J. Phys. 43, 145 (2003).

[6] M.-A. Trauwaert, Radiation and Impurity Related Deep Levels in Si, PhD thesis, IMEC-KUL, Leuven, 1995. 


\title{
KRŪVININKŲ TANKIO RELAKSACIJOS DINAMIKA PROTONAIS IR $\gamma$ SPINDULIUOTE ŠVITINTAME DIDŽIAVARŽIAME Si
}

\author{
E. Gaubas, M. Bauža
}

Vilniaus universiteto Medžiagotyros ir taikomuju mokslu institutas, Vilnius, Lietuva

\begin{abstract}
Santrauka
Ištirti rekombinacijos kinetikos doziniai, intensyvieji ir temperatūriniai kitimai didžiavaržiame $\mathrm{Si}$, išaugintame Čochralskio metodu magnetiniame lauke $(\mathrm{MCz} \mathrm{Si})$ ir apšvitintame protonais bei $\gamma$ spinduliuote, siekiant atskleisti vyraujančiu radiacinių defektų susidarymo ir pasireiškimo ypatumus. Aptikti du nepusiausvirųju krūvininkų tankio relaksacijos sandai. Sparčiajam rekombinacijos sandui priskirtos būdingos trukmès mažèja kvazitiesiškai su $\gamma$ spinduliuotès apšvitos doze, o protonais švitintuose bandiniuose šios
\end{abstract}

gyvavimo trukmės doziniai kitimai vyksta skirtinga sparta mažų, vidutinių ir didžiausių apšvitos srautų tarpuose. Lètasis krūvininkų tankio relaksacijos sandas sietinas su prilipimo vyksmais ir lemia ryškius trukmių kitimus, kaitaliojant bandinio temperatūrą tarp 100 ir $450 \mathrm{~K}$. Temperatūrinès aktyvacijos spektre aptiktos dvi efektinès trukmés kitimų smailès, iš kurių ivvertinti krūvininkų gaudyklių parametrai. Aptariami vyraujantys radiaciniai defektai, sietini su aptiktais rekombinacijos būdingụjų dydžių kitimais. 